\title{
ALAT BUKTI YANG SAH DALAM PEMBUKTIAN MENURUT UNDANG-UNDANG NOMOR 8 TAHUN 1981 TENTANG HUKUM ACARA PIDANA (KUHAP)
}

\author{
Oleh : Lorens Werluka \\ Email : $\underline{\text { lwerluka@gmail.com }}$ \\ Polda Maluku
}

\begin{abstract}
Evidence is an important process in court proceedings, public prosecutors have a burden of proof, prosecutors must prove indictments, but evidence has been collected first in the process of investigation and investigation, the proofing process in Indonesia embraced a system of minimum proof of two evidences. But the qualification of the evidence is often debated in a trial of proof. For that there needs to be the same size in determining the evidence that can be qualified to be evidence.
\end{abstract}

Keysword: evidence, regulation, court

\section{A. Pendahuluan}

alam perkara pidana, pembuktian selalu penting dan krusial. Terkadang

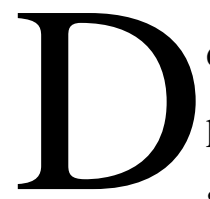
dalam menangani suatu kasus atau perkara pidana korupsi, saksi-saksi dan pelaku diam, dalam pengertian tidak mau memberikan keterangan sehingga membuat pembuktian menjadi hal yang penting ${ }^{1}$. Pembuktian memberikan landasan dan argument yang kuat kepada penyidik dan penuntut umum untuk mengajukan penuntutan. Pembuktian dipandang sebagai sesuatu yang tidak

${ }^{1}$ Bell, William R. 2017. Pratival Criminal Investigations in Correctional Facilites. Boce Raton-New York: CRC Press. hal. 114 
memihak, obyektif, dan memberikan informasi kepada hakim untuk mengambil kesimpulan suatu kasus yang disidangkan. ${ }^{2}$

Penyelesaian perakara tindak pidana meliputi beberapa tahap, yakni tahap penyelidikan dan penyidikan ditingkat penyidik, baik penyidik Polri, penyidik Kejaksaan dan penyidik Komisi Pemberantasan Korupsi dan tahap penuntutan di kejaksaan, serta tahap pemeriksaan perkara tingkat pertama di pengadilan negeri, tahap upaya hukum di Pengadilan Tinggi serta Makamah Agung, kemudian tahap eksekusi oleh eksekutor jaksa penuntun umum.

Dengan demikian, pembuktian dalam perkara pidana umum dan korupsi menyangkut beberapa institusi, yakni kepolisian, kejaksaan, komisi pemberantasan korupsi dan pengadilan.Dalam tahapan perkara pidanan sangat dimungkinkan upaya paksa dilakukan oleh aparat penegak hukum dan upaya paksa tersebut berkaitan dengan pembuktian dan upaya paksa berkaitan dengan pembuktian.

Upaya paksa selanjutnya adalah penangkapan. Berdasarkan pasal 17 Undang-undang RI Nomor 8 Tahun 1981 tentang KUHAP, perintah penangkapan dilakukan terhadap seorang yang diduga keras melakukan tindak pidanan berdasarkan bukti permulaan yang cukup.

Dalam penjelasan Pasal 17 Undang-undang RI Nomor 8 Tahun 1981 tentang KUHAP hanya dikatakan bahwa yang dimaksud dengan 'bukti permulaan yang cukup' adalah bukti untuk menduga adanya tindak pidana sesuai dengan. Bunyi Pasal 1 butir 14. Pertanyaan lebih lanjut apakah 'bukti pemulaan' sama dengan 'bukti permulaan yang cukup'? sudah tentu berebeda. Selanjutnya dalam penahanaan sebagai salah satu upaya paksa yang dapat dilakukan oleh aparat penegak hukum, baik itu polisi, jaksa penuntut umum maupun hakim, tergantung pada tahap pemeriksaan.

\footnotetext{
${ }^{2}$ Max M. Houck, 2019, Essentials Of Forensic Science: Trace Evindence, New York: An. Imprint of Infobase Publishing. hal 2
} 
Berdasarkan pasal 21 ayat (1) undang - undang RI Nomor 8 Tahum 1981 tentang KUHAP, perintah penahanan atau penahanan lanjutan dilakukan terhadap seorang tersangka atau terdakwa yang diduga keras melakukan tindak pidana berdasarkan bukti yang cukup, dalam hal adanya keadaan yang menimbulkan kekhawatiran bahwa tersangka atau terdakwa akan melarikan diri, merusak atau menghilangkan barang bukti dan atau mengulangi tindak pidana. Bila merujuk pada pasal 1 butir 14, pasal 17, berikut penjelasannya dan pasal 21 ayat (1) undang undang RI Nomor 8 Tahun 1981 tentang KUHAP, ada berbagai istilah yang kedengarannya sama, tetapi secara prinsip berbeda, yakni istilah 'bukti permulaan' 'bukti permulaan yang cukup' dan 'bukti yang cukup'. Sayangnya KUHAP tidak memberikan penjelasan lebih lanjut terkait perbedaan ketiga istilah tersebut.

Berdasarkan petunjuk pelaksanaan (juklak) Kepada Kepolisian Republik Indonesia, 'bukti permulaaan' sebagaimana dimaksud dalam pasal 1 butir 14 undang - undang RI Nomor 8 Tahun 1981 tentang KUHAP, dalam rangka menetapkan seseorang sebagai tersangka adalah berdasarkan satu alat bukti dan laporan polisi (Alat bukti keterangan Saksi dan Alat bukti Surat). Artinya, alat bukti yang dimaksudkan di sini adalah sebagaimana yang tercantum dalam Pasal 184 Undang Undang RI Nomor 8 Tahun 1981 tentang KUHAP, baik Alat Bukti Keterangan Saksi, Alat Bukti Keterangan Ahli, Alat Bukti Surat, Alat bukti Petunjuk, dan Alat Bukti Keterangan Tersangka/Terdakwa.

Bahwa kata-kata 'bukti permulaan' dalam pasal 1 butir 14 Undang-Undang RI Nomor 8 Tahun 1981 tentang KUHAP, tidak hanya sebatas alat bukti sebagaimana dimaksud dalam Pasal 184 KUHAP, namun juga dapat meliputi barang bukti yang meliputi yang dalam konteks hukum pembuktian universal dikenal dengan istilah phisycal evidence atau real evidence. Selanjutnya, untuk menakar bukti permulaan, tidaklah dapat terlepas dari pasal yang akan disangkakan kepada tersangka. Pada hakikatnya pasal yang akan dijeratkan berisi rumusan delik yang dalam konteks hukum acara pidana bukti sebagai unjuk bukti. Artinya, pembuktian adanya tindak pidana yang ada dalam suatu pasal. 
Dalam rangka mencegah kewenangan-kewenangan penetapan seseorang sebagai tersangka ataupun penangkapan dan penahanan, setiap bukti permulaan harus memiliki hubungan keterkaitan keterangan dalam bentuk alat bukti satu dengan yang lain, yang merupakan rangkaian tindak pidana atau dikonfrontasi antara saksi satu denga lainya, termasuk pula dengan calon tersangka.

Mengenai hal yang terakhir ini, dalam KUHAP kita tidak mewajibkan penyidik untuk memperlihatkan alat bukti yang ada padanya kepada si tersangka, tetapi berdasarkan doktrin, hal ini dibutuhkan untuk mencegah apa yang disebut dengan istilah unfair prejudice atau persangkaan yang tidak wajar ${ }^{3}$.

Berikutnya mengenai istilah 'bukti permulaan yang cukup', sebagaimana dimaksud dalam Pasal 17 KUHAP adalah pada bewijs minimum atau minimu bukti yang diperlukan untuk memproses seseorang dalam perkara pidana korupsi, yakni dua alat bukti. Hal ini pun masi menimbulkan perdebatan terkait dua aat bukti, yaitu apakah dua alat bukti tersebut secara kualitatif ataukah kuantitatif. Bila diurut berdasarkan Pasal 184 KUHAP, ada lima alat bukti dalam perkara pidana, yang masing-masingnya adalah;
a. Alat bukti keterangan saksi;
b. Alat bukti keterangan ahli;
c. Alat bukti surat;
d. Alat bukti petunjuk;
e. Alat bukti tersangka/terdakwa.

Secara kualitatif dua alat bukti tersebut adalah harus ada keterangan saksi dan keterangan ahli atau keterangan saksi dan surat atau keterangan ahli dan surat dan seterusnya. Tegasnya, dua alat bukti yang dimaksud secara kualitatif adalah dua dari lima alat bukti yang ada dalam Pasal 184 KUHAP. Sementara itu, secara kuantitatif, dua orang saksi sudah dihitung sebagai dua alat bukti. Dalam tataran praktis, dua alat

\footnotetext{
3 Arthur Best, 2019, Evidence: Examples and Explanation, Boston-New York-Toronto London Little, hal 4.
} 
bukti yang dimaksud adalah sceara kualitatif, kecuali perihal keterangan saksi, dua alat bukti yang dimaksud dapat secara kualitatif ataupun kuantitatif. Hal ini akan diulas lebih lanjut dalam pembahasan alat bukti keterangan saksi.

Selanjutnya perihal istilah 'bukti yang cukup' untuk melakukan penahanan sebagaimana dimaksud dalam Pasal 21 ayat (1) KUHAP. Agara tidak bias, keseluruhan pasal 21 ayat (1) dikutip "perintah penahanan atau penahan lanjutan dilakukan terhadap seorang tersangka atau terdakwa yang diduga keras melakukan tindak pidana berdasarkan bukti yang cukup, dalam hal adanya keadaan yang menimbulkan kekhawatiran bahwa tersangka atau terdakwa akan melarikan diri, merusak dan menghilangkan barang bukti dan atau tindak pidana.”

Interprestasi gramatikal-sistematis terhadap ketentuan Pasal 21 ayat (1) KUHAP adalah yang dimaksudkan dengan 'bukti yang cukup' dalam pasal a quo tidak hanya menyangkut bukti tindak pidana yang disangkakan atau didakwakan terhadap tersanga atau terdakwa, namun juga meliputi bukti bahwa tersangka atau terdakwa akan melarikan diri, merusak, atau menghilangkan barang bukti, atau mengulangi tindak pidana. Artinya, 'bukti yang cukup' disni selain merujuk pada minimu dua alat bukti atas kekhawatiran bahwa tersangka atau terdakwa akan melarikan diri, merusak atau menghilangkan barang bukti atau mengulangi tindak pidana.

Dalam perkara pidana tindak pidana ada hierarki alat bukti. Oleh karena itu, dalam penyebutan alat bukti yang sah bersarkan Pasal 184 KUHAP tidak menggunakan angka 1 sampai dengan angka 5, melainkan menggunakan huruf a sampai dengan e untuk menghindari kesan adanya hierarki dalam alat bukti. Secara eksplisit Pasal 184 ayat (1) KUHAP berbunyi sebagai berikut;

Alat bukti yang ialah:

a. Keterangan saksi 
b. Keterangan ahli;

c. Surat;

d. Petunjuk;

e. Keterangan terdakwa.

Yang akan diulaskan dalam pembahasan terkait alat bukti yang sah sebagai pembuktian menurut Undang-undang RI Nomor 8 Tahun 1981 tentang Hukum Acara Pidana (KUHAP).

\section{B. Pembahasan}

\section{Alat Bukti Keterangan Saksi:}

Definisi saksi dan definisi keterangan saksi secara tegas diatur dalam KUHP. Berdasarkan Pasal 1 angka 26 KUHP dinyatakan, "saksi adalah orang yang dapat memberikan keterangan guna kepentingan penyidikan, penuntutan, dan peradilan tentang perkara pidanan yang ia dengan sendiri, ia lihat sendiri dan ia alami sendiri”. Sementara itu, Pasal 1 angka 27 KUhP menyatakan, "keterangan saksi adalah salah satu alat bukti dalam perkara pidana yang berupa keterangan dari saksi mengenai suatu peristiwa pidana yang ia alami sendiri dengan menyebut alasan dari pengetahuannya itu."

Konstruksi Pasal 1 angka 26 juncto Pasal 1 angka 2727 junto Pasal 184 ayat (1) huruf a KUHP pada intinya mendefinisikan saksi sebagai orang yang dapat memberikan keterangan guna kepentingan penyidikan, penuntutan, dan peradilan tentang suatu perkara pidana yang ia dengar sendiri, lihat sendiri, dan alami sendiri. Jika diterjemahkan secara a contrario, keterangan atas suatu peristiwa yang tidak dilihat, didengar, atau dialami sendiri bukanlah keterangan saksi. 
Definisi saksi yang demikian merugikan tersangka atau terdakwa bilamana ia memiliki saksi alibi ${ }^{4}$ karena saksi alibi yang dibutuhkan sebagai keterangan yang meringankan bagi tersangka atau terdakwa sudah tentu ia tidak melibat, mendengar, atau mengalami sendiri mengenai perkara pidana yang disangkakan atau didakwakan.

Tegasnya, saksi alibi tidak termasuk dalam definisi saksi sebagimana yang dimaksud Pasal 1 angka 26 juncto Pasal 1 angka 27 juncto Pasal 184 ayat (1) huruf a KUHP. Ketentuan dalam ketiga pasal tersebut dapatla dikatakn lebih pada saksi yang memberatkan atau saksi de charge, ketiga pasal tersebut bertentangan dengan tentuan pasal 65 juncto pasal 116 ayat (3) KUHP. Secara tegas pasal 65 menyatakan, "tersangka atau terdakwa berhak untuk mengusahakan dan mengajukan saksi dan atau seseorang yang meiliki keahlian khusus guna memberikan keterangan yang menguntungkan bagi dirinya." Sementara itu, pasal 116 ayat (3) berbunyi: "Dalam pemeriksaan tersangka ditanyakan apakah ia menghendaki didengarnya saksi yang menguntungkan baginya dan bilamana ada, maka hal itu dicatat dalam berita acara."

Interprestasi gramatikal terhadap pasal 65 juncto Pasal 116 ayat (3) KUHP jelas ditujukan kepada saksi yang meringankan (a de charge). Dengan demikian, Pasal 1 angka 26 juncto Pasal 1 angka 27 juncto Pasal 184 ayat (1) huruf a KUHP bertentangan dengan pasal 65 juncto pasal 184 ayat (1) huruf a KUHP bertentangan dengan pasal 65 juncto pasal 116 ayat (3) ayat (4) KUHP, padahal definisi saksi mestinya berlaku, baik pada saksi yang memberatkan maupun yang meringankan.

Bila dihubungkan dengan empat hal fundamental dalam hukum pembuktian sebagaimana diutarakan di atas, arti penting saksi bukan terletak pada dia melihat, mendengar, atau mengalami sendiri suatu peristiwa pidana, melainkan apakah kesaksiannya itu relevan ataukah tidak dengan perkara pidana

\footnotetext{
${ }^{4}$ Eddy O. S. Hiariej. 2018. Teori Hukum Pembuktian, Penerbit Erlangga.
} 
yang sedang diproses. Mengenai apakah keterangan saksi tersebut admissible ataukah inadmissible, hal tersebut merupakan kewenangan hakim untuk menentukannnya dalam rangka penilaian terhadap kekautan pembuktiannya dari bukti-bukti yang diajukan oleh penuntut umum atau terdakwa.

Bila dibandingkan dengan definisi saksi yang terdapat dalam Pasal 324 ayat (1) Wetboek van Strafvordering di Negara Belanda, jelas menunjukan perbedaan prinsip. Pasal 3442 (1) Wetboek van Strafvordering mendefinisikan saksi : "onder verklaring vaneen getguige wordt verstaan zijne bij het onderzoek op de terechtzitting gedane medeeling van feiten of omstandigheden, welke hij zelf waargenomen og ondervonden heft" (keterangan saksi adalah hal yang dinyakan di penyidikan dan di depan sidang pengadilan mengenai suatu peristiwa atau keadaan yang dialami atau diketahuinya). Definisi yang demikian bersifat universal dan dapat ditafsirkan baik oleh saksi yang meringankan maupun saksi yang memberatkan.

Dalam perkembangannya definisi saksi sebagaimana dimaksud dalam pasal 1 angka 26 juncto Pasal 1 angka 27 juncto pasal 184 ayat (1) huruf a KUHP diperluas berdasarkan putusan Mahkamah Konstitusi Nomor 65/PPU-VII/2010 tanggal 8 Agustus 2011. Secara aksplisit putusan MK dalah amarnya menyatakan sebagai berikut:

"Pasal 1 angka 26 dan angka 27; Pasal 65; Pasal 116 ayat (3) dan ayat (4); serta pasal 184 ayat (1) huruf a Undang-Undang Nomor 8 tahun 1981 tentang Hukum Acara Pidana (LN Republik Indonesia tahun 1981 Nomor 76 dan Tambahan Lembaran Negara Republik Indonesia Nomor 3209), tidak dimaknai termasuk pula "orang yang dapat memberikan keterangan dalam rangka penyidikan, penuntutan, dan peradilan suatu tindak pidana yang tidak selalu ia dengar sendiri, ia lihat sendiri dan ia alami sendiri"; Pasal 1 angka 26 dan angka 27; Pasal 65; Pasal 116 ayat (3) dan ayat (4); serta pasal 184 ayat (1) huruf a Undang-Undang Nomor 8 Tahun 1981 tentang Hukum Acara Pidana (LN RI tahun 1981 Nomor 76 dan Tambahn LN RI Nomor 3209), tidak dimaknai termasuk pula "orang yang dapat memberikan keterangan dalam rangka penyidikan, penuntutan, dan peradilan suatu tindak pidana yang tidak selalu ia dengar sendiri, ia lihat sendiri, dan ia alami sendiri." 
Dengan demikian, berdasarkan putusan MK, definisi keterangan saksi sebagai alat bukti adalah keterangan dari saksi mengenai suatu peristiwa pidana yang ia dengar sendiri, ia lihat sendiri, dan ia alami sendiri dengan menyebut alasan pengetahuannya itu, termasuk pula keterangan dalam rangkan penyidikan, penuntutan, dan peradilan suatu tindak pidana yang tidak selalu ia dengar sendiri, ia lihat sendiri, dan ia alami sendiri.

Saksi yang melihat secara langsung terjadinya suatu tindak pidanan sering siberu dengan istilah saksi mata atau eyewitness. Saksi mata merupakan bukti yang paling penting dalam perkara pidana. Cliford dan David mengemukakan ada tiga tahapan dalam penyidika untuk mengidentifikasi saksi mata dalam rangka penemuan tersangka.

Pada fase pertama, saksi mata disuruh menceritakan segala informasi yang ia lihat dan informasi lainnya yang berkaitan dengan kejahatan. Polisi dapat menggunakan program komputer atau sketsa wajah si pelaku. Pada fase kedua, polisi mencari tersangka. Pada fase ketiga, polisi meminta saksi mata untuk mengidentifikasi pelaku dari sejumlah calon tersangka yang dimiliki oleh polisi secara langsung dengan mempertunjukan calon tersangka tersebut ${ }^{5}$.

Berdasarkan KUHP, keterangan saksi sebagai bukti yang sah, selain keterangan tersebut mengenai apa yang ia lihat, ia dengar, atau ia alami sendiri, termasuk pula peluasan sebagaimana yang diputuskan $\mathrm{MK}$, juga harus disampaikan di depan sidang pengadilan dan di bawah sumpah. Ada pendekatan dalam prkatek pengadilan., apakah keterangan saksi yang diberikan melalui teleconference dapat dikatakan sebagai alat bukti keterangan saksi yang sah menurut KUHP.

${ }^{5}$ Tong, Stephen. Robin P. Bryant \& Miranda A.H. Horvath. 2019. Understanding Criminal Investigations. Wiley-Blackwell; A. John Wiley \& Sons, ltd, Publications. Hal. 94 dan 96 
Seperti yang kita telah ketahui dalam praktek pengadilan pemeriksaan sebagai saksi pernah dilakukan melalui teleconference, antara lain kasus korupsi dana Yanatera Bulog yang menampilkan manta Presiden B.J. Habibie secara teleconference dari Jerman dan kasus terorisme dengan terdakwa Abu Bakar Ba'asyir yang menampilkan saksi secara teleconference dari Malaysia. Terhadap pertanyaan sah atau tidaknya keterangan saksi sebagai alat bukti melalui teleconference, penting diketahui hakikat saksi memberikan keterangan di depan sidang pengadilan.

Pada hakikatnya keterangan saksi sebagai alat bukti yang sha, yaitu keterangan yang diberikan di depan sidang pengadilan ditujukan dengan maksud keterangan tersebut dapat dikonfirmasi oleh hakim, Jaksa Penuntut Umum, dan Advokat. Seandainya terdapat pertentangan antara saksi yang satu dengan saksi yang lain, dapat dilakukan cross check secara langsung, Kesaksian teleconference dapat memenuhi hakikat secara langsung di pengadilan. Dengan demikian, keterangan saksi yang diberikan secara teleconference mempunyai kekuatan sebagia alat bukti yang sah.

Prinsip satu saksi bukanlah atau unus testis nullus testis (Latin) atau een getuige geen getuige (Belanda) juga diatur dalam KUHAP. Hal ini tersimpul dalam Pasal 185 Ayat (2) KUHAP yang menyatakan, "Keterangan seorang saksi saja tidak cukup untuk membuktikan bahwa terdakwa bersalah terhadap perbuatan yang didakwakan kepadanya." Ketentuan ini disusun oleh ketentuan Pasal 185 ayat (3) KUHAP yang berbunyi, "Ketentuan sebagaimana dimaksud ayat (2) tidak berlaku apabila disertai dengan suatu alat bukti yang sah lainnya."

Interprestasi gramatikal sistematis terhadap Pasal 185 ayat (2) juncto Pasal 185 ayat (3) KUHAP; tidak hanya berkaitan dengan prinsip unus testis nullus testis,tetapi juga erat kaitannya dengan prinsip minimum pembuktian untuk menyatakan terdakwa bersalah dalam perkara pidana, yaitu dua alat bukti. Sebagaimana telah disinggung di atas bahwa minimum alat bukti adalah dua alat 
bukti secara kualitatif, kecuali terhadap alat bukti keterangan saksi, minimun dua alat bukti juga dapat diartikan secara kualitatif.

Hal ini dapat diaktfikan secara a contrario terhadap ketentuan Pasal 185 ayat (2). Jika keterangan seseorang saksi tidak cukup untuk membuktikan bahwa terdakwa bersalah terhadap perbuatan yang didakwakan kepanya, keterangan lebih dari seorang saksi sudah cukup membuktikan terdakwa bersalah terhadap perbuatan yang didakwakan kepadanya selama menimbulkan keyakinan hakim. Tegasnya, yakni dua alat bukti.

Keterangan saksi yang berdiri sendiri-sendiri tentang suatu kejadian atau keadaan dapat digunakan sebagai alat bukti yang sah apabila keterangan saksi itu memiliki hubungan satu degnan yang lain sedemikian rupa sehingga dapat membenarkan adanya suatu kejadian atau keadaan tertentu. Pendapat yang diperoleh dari hasil pemikiran bukanlah merupakan keterangan saksi. Dalam menilai kebenaran keterangan seorang saksi, hakim harus dengan sungguhsungguh memperhatikan persesuaian keterangan saksi satu dengan yang lain. selain itu, harus diperhatikan pula persesuaian antara keterangan saksi dengan alat bukti lain. perihal kesesuaian antara satu dengan saksi yang lain dan kesuaian antara satu saksi dan alat bukti yang lain dalam konteks teori dikenal dengan istilah corroborating evidence. Demikian juga harus diperhaikan cara hidup dan kesesuaian saksi serta segala sesuatu yang pada umumnya bias mempengaruhi dapat atau tidaknya keterangan itu dipercaya.

Keterangan saksi yang tidak disumpah, meskipun sesuai satu dengan yang lain, bukan merupakan alat bukti. Namun, apabila keterangan itu sesuai dengan keterangan dari saksi yang disumpah, keterangan itu dapat dipergunakan sebagai keterangan tembahan alat bukti sah yang lain. artinya keterangan saksi yang tidak disumpah dapat memperkuat keyakinan hakim. Hal lain yang juga diatur dalamm pembuktian perkara pidana di Indonesia adalah masalah tertimonium de auditu yang secara harfiah berarti kesaksian yang diperoleh dari orang lain. Pasal 185 (1) KUHAP menyatakan keterangan saksi sebagai alat bukti ialah hal yang 
dinyatakan saksi di sidang pengadilan. Selanjutnya dalam penjelasannya ditegaskan bahwa dalam keterangan saksi, tidak termasuk keterangan yang diperoleh dari orang lain atau testimonium de auditu. Artinya, KUHAP secara tegas menyatakan bahwa testimonium de auditu bukanlah alat bukti.

\section{Alat bukti Keterangan Ahli}

Definisi keterangan ahli menurut KUHAP dalah: "keterangan yang diberikan seorang yang memiliki keahlian khusus tentang hal yang diperlukan oleh seseorang untuk membuat terang suatu perkara pidana guna kepentingan pemeriksaan." Keterangan ahli dinyatakan sah sebagai alat bukti jika dinyatakan di depan persidangan dan di bawah sumpah. Menurut ketentuan Pasal 186 KUHAP, keterangan ahli adalah hal yang seseorang ahli nyatakan di bidang pengabdiannya. Dalam penjelasan, dikatakan bahwa keterangan ahli ini dapat juga sudah diberikan pada waktu pemeriksaan oleh penyidik atau penuntut umum yang dituangkan dalam suatu bentuk laporan dan dibuat dengan mengingat sumpah diwaktu ia menerima jabatan atau pekerjaan.

Merujuk pada ketentuan dalam KUHAP, keahlian dari seseorang yang memberikan keterangan ahli tidak hanya berdasarkan pengetahuan yang ia miliki melalui pendidikan formal, namun keahlian itu juga dapat diperoleh berdasarkan pengalamannya. Keahlian tersebut juga bisa berkaitan dengan jabatan dan bidang pengabdiannya. Karena berdasarkan KUHAP, tidak ada persyaratan kualifikasi seorang ahli harus memenuhi jenjang akademik tertentu.

Patut diperhatikan bahwa KUHAP membedakan keterangan seorang ahli di persidangan dan keterangan ahli secara tertulis yang disampaikan di depan sidang pengadilan. Jika seseorang ahli memberikan keterangan secara langsung di depan sidang pengadilan dan di bawah sumpah, keterangan tersebut adalah alat bukti keterangan ahli yang sah. Sementara itu, jika seseorang ahli di bawah sumpah telah memberikan keterangan tertulis di luar persidangan dan keterangan tersebut 
dibacakan di depan sidang pengadilan, keterangan ahli tersebut merupakan alat bukti surat dan alat bukti keterangan ahli.

Visum et revertum kendatipun isinya berupa keterangan ahli yang diberikan dibawah sumpah dan di luar persidangan pengadilan, namun kualifikasinya juga termasuk sebagai alat bukti surat dan bukan alat bukti keterangan ahli. Dalam persidnagan keterangan ahli ini dibutuhkan untuk menerangkan suatu hal tertentu yang dalam menjelaskannya membutuhkan keahlian khusus.

Keterangan ahli berupa dibutuhkan untuk memberi penjelasan terkati physical evidence atau real evidence. Demikian pula keterangan ahli dibutuhkan untuk menrangkan hal-hal diluar pengetahuan hukum. Akan tetapi, dapat saja keterangan ahli juga menyangkut keterangan hukum terkati dengan dasar hukum atau alasan yang menjadi pokok perkasa termasuk pul didalamnya analisis atau pengertian elemen-elemen suatu tindak pidana yang didakwakan.

Keterangan ahli biasanya bersifat umum berupa pendapat atau yang berkaitan dengan perkara tersebut. ahli tidak diperkenankan memberikan penilaian terhadap kasus konkret yang sedang disidang. Oleh karena itu, pertanyaan kepada ahli biasanya bersifat hipotesis atau pertanyaan bersifat umum. Ahli pun tidak dibolehkan memberikan penilaian terhadap salah satu tidaknya terdakwa berdasarkan fakta persidangan yang ditanyakan kepadanya.

\section{Alat Bukti Surat}

Jenis surat yang dapat dipergunakan sebagai alat bukti dicantumkan dalam Pasal 187 KUHAP. Surat tersebut dibuat atas stau dikuatkan dengan sumpah jabatan atau dikuatkan dengan sumpah. Jenis surat yang dimaksud adalah :

Pertama, berita acara dan surat lain dalam bentuk resmi yang dibuat oleh pejabat umum yang berwenang atau yang dibuat dihapannya, yang memuat keterangannya tentang kejadian atau keadaan yang didengar, dilihat atau dialaminya sendiri, disertai dengan alasan yang jelas dan tegas tentang keterangannya itu. 
Sebagai contoh, akte perjanjian yang dibuat oleh para pihak di hapadan notaris. Demikian pula akte yang dibuat oleh pejabat umum seperti kepala desa, lurah, camat, dan lain sebagainya Menurut Wijono Prodjidukoro, suatu akat autentik yang dijadikan alat bukti pada perkara-perkara yang bersifat mengikat hakim, kecuali jika ada bukti sebaliknya, namun hal tersebut berbeda dengan perkara pidana.

Dalam perkara pidana, tidak ada satu bukti pun yang mengikat hakim perihal kekuatan pembuktian. Hakim pidana harus selalu memikirkan apa ia yakin atas kesalah terdakwa. Jika ada akte autentik yang diajukan dalam perkara pidana, hakim, untuk mempunyai keyakinan tentang ketiadaan kesalah terdakwa, tidak memerulkan bukti yang berlawanan, seperti halnya dengan hakim perdata ${ }^{6}$. Hal yang dikemukakan oleh Prodjodikoro dapat penulis pahami. Hal ini mengingat pembuktian dalam perkara pidana di Indonesia menganut pembuktian bebas. Artinya, hakim bebas untuk meyakini atau tidak menyakini alat-alat bukti yang sah.

Kedua, surat yang dibuat menurut ketentuan peraturan perundangundanganan atau surat yang dibuat oleh pejabat mengenai hal yang diperuntukan bagi pembuktian sesuatu hal atau sesuatu keadaan. Contohnya, untuk membuktikan adanya perkawinan, ada surat nikah. Untuk membuktikan adanya kematian, ada akte kematian dan untuk membuktikan tempat tinggal seseorang ada kartu tanda penduduk (KTP).

Ketiga, surat keteragan ahli yang memuat pendapat berdasarkan keahliannya mengenai sesuatu al atau suatu kedaan yang meminta secara resmi dari padanya. Misalnya adalah hasil visum et repertum yang dikeluarkan oleh seorang dokter. Visum tersebut dapat dibuat berdasarkan permintaan korban atau permintaan aparat penegak hukum untuk kepentingan penyidikan, penuntutan atau persidangan.

\footnotetext{
${ }^{6}$ Wirjono Projodikoro, 2018, Hukum Acara Pidana, Refika AditamaBandung. hal. 79.
} 
Keempat, surat lain yang biasa berlaku jika ada hubungannya dengan isi dari alat pembuktian yang lain. surat jenis ini hanya mengandung nilai pembuktian apabila isi surat tersebut adalah hubungannya dengan alat bukti lain. Berdasarkan undang-undang Informasi dan Transaksi Elektronik, Informasi elektronik dan atau dokumen elektronik dan atau hasil cetakannya merupakan alat bukti yang sah menurut hukum acara. Dokumen elektronik tidaklah dapat dijadikan alat bukti jika terdapat suatu surat, termask pula akta notaris atau akta yang dibuat oleh pejabat pembuat akte. Dalam hal suarat-surat tidak memenuhi persyaratan untuk dinyatakan sebagai bukti surat, surat-surat tersebut dapat dipergunakan sebagai petunjuk. Akan tetapi, mengenai dapat atau tidaknya surat dijadikan alat bukti petunjuk, semuannya diserahkan kepada pertimbangan hakim.

\section{Alat Bukti Petunjuk}

Berdasarkan Pasal 188 ayat (1) KUHAP, petunjuk didefinisikan sebagai perbuatan, kejadian atau keadaan, yang karena persesuainnya, baik antara yang satu dengan yang lain maupun dengan tindak pidana itu sendiri, menandakan bahwa telah terjadi suatu tindak pidana dan siapa pelakunya. Petunjuk tersebut hanya dapat diperoleh dari keterangan saksi, surat, dan keterangan terdakwa.

Penilaian atau kekuatan pembuktian suatu petunjuk dalam setiap keadaan tertentu dilakukan oleh hakim dengan arif dan bijaksana setelah ia mengatakan pemeriksaan dengan penuh kecermatan dan kesaksamaan berdasarkan hati nuraninya. Tegasnya, syarat-syarat petunjuk sebagai alat bukti harus mempunyai persesuaian satu sama lain atas perbuatan yang terjadi. Selain itu, keadaan-keadaan tersebut berhubungan satu sama lain dengan kejahatan yang terjadi dan berdasarkan pengamatan hukum yang diperoleh dari keterangan saksi, surat, atau keterangan terdakwa.

Adami Chazawi mengungkapkan persyaratan suatu petunjuk adalah sebagai berikut : 
- Adanya perbuatan, kejadian, dan keadaan yang bersesuaian, perbuatan, kejadian, dan keadaan merupakan fakta-fakta yang menunjukan telah terjadinya tindak pidana, menunjukan terdakwa yang melakukan, dan menunjukan terdakwa bersalah karena melakukan tindak pidana tersebut.

- Ada dua persesuaian, yaitu persesuaian antara masing-masing perbuatan, kejadian, dan keadaan satu sama lain ataupun bersesuaian antara perbuatan, kejadian, atau keadaan dengan tindak pidana yang didakwakan.

- Persesuaian yang demikian itu menandakan atau menunjukan adanya dua hal, yaitu menunjukan bahwa benar telah terjadi suatu tindak pidana dan menunjukan siapa pelakunya. Unsur ini merupakan kesimpulan bekerjanya proses pembentukan alat bukti petunjuk, yang sekaligus merupakan tujuan dari alat bukti yang sah.

Dalam konteks teori pembuktian, petunjuk adalah circumstantial evidence atau bukti tidak langsung yang bersifat sebagai pelengkap atau accessories evidence, artinya, petunjuk bukanlah alat bukti mandiri, namun alat bukti sekunder yang diperoleh alat bukti primer, dalam hal ini adalah keterangan saksi, surat, dan keterangan terdakwa. Mengapa keterangan ahli, merupakan alat bukti primer atau mandiri, tidak dijadikan sebagai sumber diperolehnya suatu alat bukti petunjuk, hal ini berkaitan dengan sifat keterangan ahli adalah berdasarkan subjektivitas seorang ahli, kendali pun keterangan ahli haruslah disampaikan secara objektif.

Alat bukti petunjuk otoritas penuh dan subjektivitas hakim yang memastikan perkara tersebut. hakim dalam mengambil kesimpulan tentang pembuktian sebagi suatu petunjuk haruslah menghubungkan alat bukti yang satu dengan alat bukti yang lainnya dan memiliki persesuaian digunakan 
dalam hal alat-alat bukti yang ada belum dapat membentuk keyakinan hakim tentang kejadian tindak pidana dan keyakinan bahwa terdakwa yang melakukannya.

Perihal hakim belum dapat keyakinan, ada tiga kemungkinan. Pertama, pembuktian yang ada belum memenuhi syarat minimum, yakni dua alat bukti. Kedua, telah memenuhi minimum pembuktian, namun menghasilkan masing-masing fakta yang berdiri sendiri. Jika demikian halnya, alat bukti petunjuk dapat memenuhi syarat minimum pembuktian. Ketiga, alat bukti yang sah lebih dari cukup minimum pembuktian, namun belum meyakinkan hakim tentang terjadinya tindak pidana dan terdakwalah yang melakukannya. Dalam hal ini petunjuk dipergunakan untuk menambah keyakinan hakim.

Bila kita bandingkan dengan strafvordering (hukum acara pidana) yang berlaku di negara Belanda, berdasarkan Pasal 339 WvS. Petunjuk dapat disamakan dengan eigen waarneming van de rechter yang diartikan sebagai pengamatan atau pengetahuan hakim. Oleh karena itu, kekuatan pembuktian alat bukti petunjuk didasari pengamatan hakim untuk menilai persesuaian antara fakta-fakta yang ada dengan tindak pidana yang didakwakan dan juga persesuaian antara masing-masing alat bukti dengan fakta dan tindak pidana yang didakwakan.

Dari kata adanya persesuaian dapat disimpulkan bahwa sekurangkurangnya harus ada dua petunjuk untuk mendapatkan bukti yang sah. Setiap petunjuk belum tentu mepunyai kekuatan pembuktian yang sama. Kekuatan pembuktiannya terletak pada hubungan banyak atau tidaknya perbuatanperbuatan yang dianggap sebagai petunjuk tersebut sesuai dengan perbuatan yang didakwakan kepada terdakwa. Penilaian terhadap alat bukti petunjuk tidak dilakukan oleh undang-undang, melainkan diamanatkan kepada hakim, yang harus menilai dengan arif, bijaksana, penuh kecermatan, dan keseksamaan. 


\section{Alat Bukti Keterangan Terdakwa}

Keterangan terdakwa dalam konteks hukum pembuktian secara umum dapat disamakan degnan bukti pengakuan atau conferssions evidence, Menurut Mark Frenk, John Yarbrough, dan Paul Ekman, pengakuan tanpa bukti-bukti yang memperkuat kesaksin dengan sendirinya tidak bernilai apa-apa. KUHAP memberikan definisi keterangan terdakwa sebagai apa yang terdakwa nyatakan disidang tentang perbuatan yang ia lakukan atau yang ia ketahui sendiri atau ia alami sendiri:

Keterangan terdakwa yang dikatakan mengandung nilai pembuktian yang sah adalah sebagai berikut.

- Keterangan harus dinyatakan di depan sidang pengadilan

- Isi keterangannya mengenai perbuatan yang dilakukan terdakwa, segala hal yang diketahuinya, dan kejadian yang dialaminya sendiri;

- Keterangan tersebut hanya dapat digunakan terhadap dirinya sendiri. Artinya, mengenai memberatkan atau meringankannya keterangan terdakwa di sidang pengadilan, hali ini berlaku terhadap dirinya sendiri dan tidak boleh dipergunakan untuk meringankan atau memberatkan orang lain atau terdakwa lain dalam perkara yang sedang diperiksa;

- Keterangan tersebut tidak cukup untuk membuktikan bahwa ia bersalah melakukan perbuatan yang didakwakan kepadanya, yang sedang diperiksa;

- Keterangan tersebut tidak cukup untuk membuktikan bahwa ia bersalah melakukan perbuatan yang diakawakan kepadanya, melainkan harus disertai dengan alat bukti yang lain; 
Keterangan terdakwa yang diberikan di luar sidang dapat digunakan untuk membantu menemukan bukti di sidang, asalkan keterangan itu di dukung oleh suatu alat bukti yang sah sepanjang mengenai hal yang didakwakan kepadanya. Pemeriksaan terhadap terdakwa juga sudah dimulai pada tahap penyidikan dan dituangkan dalam berita acara pemeriksaan.

Adakalanya keterangan tersangka atau terdakwa pada tahap penyidikan berubah-ubah sehingga menimbulkan kesulitan bagi penyidik untuk mengungkapkan fakta yang sebenarnya. Tidak jarang dalam menghadapi keterangan tersangka atau terdakwa sering berubah-ubah pada tahap penyidikan, penyidik menggunakan alat pendekteksi kebohongan. Terhadap alat pendeteksi kebohongan yang menggunakan metode metode psikofisolofi dan nada yang menggunakan tehnik paralinguistic.

Metode psikofisiologi memadukan aspek psikologi dan biologi yang menimbulkan keyakinan bahwa seseorang yang berbohong menciptakan konflik secara sadar yang memicu kepanikan atau ketakutan disertai dengan perubahan psikologi yang dapat diukur dan diintreprestasikan, Detektor kebohongan berkerja dengan menguji poligraf yang mencakup serangkaian pertanyaan kepada tersangka yang dihubungkan dengan sensor-sensor yang mengirim lewat kabel ke instrument dan memperlihatkan reaksi fisikologi tersangka seperti perubahan denyut jantung, pernafasan, dan kulit tersangka.

Metode Paralingnguistik didasarkan kepada perhitungan kata terhadap jawaban tersangka atas pertanyaan penyidik. Secara linguistic, ada tiga perbedaan dalam cara pembohong berbicara. Pertama, pembohong cenderung menggunakan lebih sedikit kata ganti personal. Kedua, pembohong mempergunakan lebih banyak kata yang berkonotasi emosi negatif. Ketiga, pembohong mencertikan peristiwa yang kurang kompleks bila dibandingkan orang yang lain yang berkata benar tentang peristiwa itu. Kendali pun deteksi kebohongan dapat memberikan penilaian terhadap keterangan seorang tersangka atau terdakwa, hasil deteksi tersebut tidaklah dapat dijadikan bukti di depan sidang pengadilan. Hanya 
keterangan terdakwa di depan sidang pengadilan yang akan menjadi alat bukti. Keterangan terdakwa sebagai alat bukti yang sempurna harus disertai keterangan yang jelas tentang keadaan-keadaan yang berkaitan dengan tindak pidana dilakukan olehnya. Keterangan tersebut, semua atau sebagian, harus cocok dengan keterangan korban atau dengan alat-alat bukti lainnya.

\section{Penutup}

Hukum pembuktian merupakan ketentuan-ketentuan mengenai pembuktian yang meiputi alat bukti, barang bukti, cara mengumpulkan dan memperoleh bukti bisa disebut pulbaket dan sampai pada penyampaaian bukti di pengadilan serta kekuatan pembuktian dan beban pembuktian Sementara itu, hukum pembuktian pidana korupsi adalah ketentuan-ketentuan meengeni pembuktian yang meliputi alat bukti, barang bukti, cara mengumpulkan dan memperoleh bukti sampai penyampaian bukti di pengadilan serta kekuatan pembuktian dan beban pembuktia dalam perkara pidana korupsi.

Berkaitan dengan hukum pembuktian yang telah dibahas dalam tulisa ini, juga telah dibahas mengenai alat-alat bukti, yang fokus pada hukum pembuktian semata, sehingga dapat mempermudah proses penyidikan oleh aparat penegak hukum. 


\section{DAFTAR PUSTAKA}

Bell, William R. 2019. Pratival Criminal Investigations in Correctional Facilites. Boce Raton-New York: CRC Press.

Max M. Houck, 2019, Essentials Of Forensic Science: Trace Evindence, New York: An. Imprint of Infobase Publishing.

Arthur Best, 2018 Evidence: Examples and Explanation, Boston-New York-Toronto London Little.

Eddy O. S. Hiariej. 2018. Teori Hukum Pembuktian, Penerbit Erlangga..

Tong, Stephen. Robin P. Bryant \& Miranda A.H. Horvath. 2019. Understanding Criminal Investigations. Wiley-Blackwell; A. John Wiley \& Sons, ltd, Publications.

Wirjono Projodikoro, 2018. Hukum Acara Pidana, Refika AditamaBandung. 